\title{
Perbedaan Adversity Quotient Ditinjau Dari Coping Stress dan Self Efficacy
}

\author{
Diny Atrizka, Kevin Sanjaya, Dea Vanthera, Wulandari, Khrisna Sanubari Limbong, Rizky Yusfasari \\ Universitas Prima Indonesia, Indonesia \\ Email: diny.dinyrizk@gmail.com, vinsanjaya@gmail.com, vantheradea98@gmail.com, wulandari.lan.wd98@ gmail.com, \\ sanubarilimbong@gmail.com, ryusfasari@gmail.com
}

\begin{abstract}
This study aimed to determine the difference adversity quotient in terms of coping stress and self-efficacy of tenth grade students in SMA Swasta Medan. The population of this study was all of the students of tenth grade in SMA Swasta Medan. The subjects used in this study were 146 students who were selected using the disproportionate stratified random sampling method. This study was a comparative quantitative, data collected used Likert Scale which is adversity quotient (AQ), coping stress (CS), and self-efficacy (SE) scale. In this study the data analysis technique used is analysis of varians (ANOVA). The assumptions test consisted of an normality test, a homogenity test, and a hypothesis test.The result of data analysis showed a significant difference adversity quotient in terms of coping stress with Sig .000 $<p=.05$ and a significant difference adversity quotient in terms of self-efficacy with Sig .000 $<p=.05$ that owned by the students. The conclusion obtained from this study is a proven hypothesis, namely the difference between adversity quotient (AQ) in terms of coping stress (CS) and adversity quotient $(A Q)$ in terms of self-efficacy $(S E)$, where the contribution percentage of coping stress $(C S)$ in influencing adversity quotient $(A Q)$ was $16.6 \%$ and self-efficacy (SE) in influencing adversity quotient (AQ) was 19.5\%, the rest was developed by other factors that were not appropriate by the researcher.
\end{abstract}

Keywords: adversity quotient, coping stress, self efficacy

\begin{abstract}
Abstrak
Penelitian ini bertujuan untuk mengetahui perbedaan adversity quotient ditinjau dari coping stress dan self efficacy pada siswa/i kelas X SMA Swasta Medan. Populasi dalam penelitian ini adalah seluruh siswa-siswi kelas X di SMA Swasta Medan dengan jumlah sampel 146 orang dengan menggunakan metode penarikan sampelnya yaitu disproportionate stratified random sampling. Penelitian ini merupakan penelitian kuantitatif yang bersifat komparatif. Pengumpulan data menggunakan Skala Likert yang berupa skala adversity quotient (AQ), coping stresss (CS), dan self efficacy (SE). Dalam penelitian ini teknik analisis data yang digunakan adalah teknik Anava One Way (Anova). Uji asumsi yang dilakukan adalah uji normalitas, uji homogenitas dan uji hipotesa. Hasil penelitian menunjukan bahwa terdapat perbedaan yang signifikan antara adversity quotient ditinjau dari coping stress dengan Sig .000 $<\mathrm{p}=.05$ dan juga terdapat perbedaan yang signifikan antara adversity quotient ditinjau dari self efficacy dengan Sig .000 $<\mathrm{p}=.05$ yang dimiliki oleh siswa/i. Kesimpulan yang diperoleh dari penelitian ini adalah bahwa hipotesa terbukti, yaitu adanya perbedaan antara adversity quotient $(A Q)$ ditinjau dari coping stress $(C S)$ dan adversity quotient $(A Q)$ ditinjau dari self efficacy (SE), di mana presentase kontribusi coping stress (CS) dalam mempengaruhi adversity quotient (AQ) sebesar 16.6\% dan kontribusi self efficacy (SE) dalam mempengaruhi adversity quotient $(A Q)$ ) sebesar $19.5 \%$, selebihnya dipengaruhi oleh faktor-faktor lain yang tidak diteliti oleh peneliti.
\end{abstract}

Kata kunci: adversity quotient, coping stress, self efficacy

\section{Pendahuluan}

Pendidikan pada masa sekarang sangatlah dipandang sebagai suatu hal yang diperlukan dalam mendukung terciptanya manusia yang cerdas dan mampu bersaing di masyarakat. Berdasarkan Kamus Bahasa Indonesia (KBBI) pendidikan merupakan suatu proses pendewasaan manusia melalui perubahan sikap dan perilaku seseorang atau sekelompok manusia, pendewasaan manusia ini dapat dilakukan dengan upaya pengajaran dan pelatihan yang didapat melalui proses pembelajaran di sekolah. Penelitian ini berfokus pada siswa/i yang menduduki tingkat pendidikan Sekolah Menengah Atas (SMA). Menurut Santrock (dalam Widarnandana \& Simarmata, 2015), siswa/i yang menduduki tingkat pendidikan SMA merupakan remaja akhir yang memiliki usia di antara 18 tahun hingga 20 tahun. Remaja cenderung memiliki kehidupan yang tidak terlepas dari berbagai permasalahan dalam setiap tahap perkembangannya, masa ini disebut dengan masa storm and stress, yaitu masa yang penuh emosi dan menimbulkan konflik (Haull dalam Yusuf, 2001; Santrock dalam P \& Desiningrum, 2018). Terdapat sebuah kasus yang terjadi di SMAN 5 Denpasar, ada seorang siswa yang tampak kasak-kusuk di tempat duduknya saat mengikuti Ujian Nasional (UN) di SMAN 5 Denpasar, Bali. Siswa tersebut membawa handphone yang ditaruh di antara pahanya sembari melihat kertas yang berisi soal ujian, sesekali tangan kirinya membuka handphone tersebut. Tindakan ini merupakan tindakan yang sering disebut dengan tindakan menyontek (Agustina, 2016). Hal ini tampak serupa

Diterima Redaksi : 07-05-2020 | Selesai Revisi : 12-06-2020 | Diterbitkan Online : 12-06-2020 
dengan hasil observasi yang dilakukan peneliti selama dua bulan baik observasi langsung maupun tidak langsung di salah satu sekolah SMA Swasta di Medan, keadaan sekolah pada saat jam istirahat terdengar teriakan siswa/i dari dalam kelas, mereka meluapkan stres mereka sehabis jam pelajaran. Mereka mengalami stres dalam belajar dikarenakan sulitnya memahami pelajaran yang dipaparkan oleh guru mereka, sehingga siswa/i akhirnya bermain handphone atau bercerita dengan teman di kelas. Ketika menghadapi ujian sekolah, terdapat beberapa siswa/i mengalami kesulitan dalam menjawab soal ujian, akhirnya mereka menyontek demi mendapatkan nilai yang baik. Tindakan menyontek ini dapat menyebabkan mereka menjadi malas belajar hingga menjadi suatu kebiasaan yang buruk. Upaya dalam menghadapi kesulitan-kesulitan siswa/i, maka diperlukan AQ yang baik pada siswa/i. Menurut Stoltz (2000), AQ adalah suatu konsep mengenai kecerdasan menghadapi hambatan dan kemampuan bertahan dalam menghadapi berbagai kesulitan yang ada di berbagai aspek kehidupannya. Apabila siswa/i tidak menemukan penyelesaian atas kesulitan yang dihadapi, maka hal ini dapat menimbulkan keadaan stres. Satu langkah yang dapat dilalui untuk mengurangi dan memanajemen stres adalah dengan CS. Menurut Sarafino (dalam Maryam, 2017), coping adalah usaha untuk mengatasi stres yang terjadi. Lazarus dan Folkman (dalam Davison, dkk., 2006), menyebutkan ada dua dimensi coping, yaitu problem focused coping merupakan cara yang digunakan individu dalam mengurangi ketegangan lebih mengarah kepada tindakan pemecahan masalah yaitu dengan memodifikasi atau meminimalisir situasi yang sedang dihadapi dan emotion focused coping merupakan cara individu mengurangi perasaan tidak nyaman tersebut dengan menggunakan metode pertahanan, seperti penilaian positif, penyangkalan, atau berpikir dengan penuh pengharapan. SE memiliki peran yang sangat penting dalam kehidupan sehari-hari seseorang dalam mencari jalan keluar dari pemasalahan yang dihadapi, khususnya permasalahan remaja saat menghadapi kesulitan belajar (Bandura, dalam Rahmi, dkk., 2017). SE menurut Bandura (dalam Ghufron \& Risnawita, 2018) adalah keyakinan yang dimiliki individu akan kemampuan dirinya dalam melakukan tindakan-tindakan yang diperlukan untuk mencapai tujuan tertentu. Bandura (dalam Kurniasari, dkk., 2018), SE terdapat tiga dimensi, yaitu pertama level, hal ini berkaitan dengan tingkat kesulitan yang dihadapi, yang kedua yaitu generality merupakan suatu keyakinan individu dalam menyelesaikan tugas dengan baik dan yang ketiga yaitu strength, berkaitan dengan kekuatan dan keyakinan yang dimiliki individu mengenai kemampuannya dalam menyelesaikan masalah yang dihadapi. Penelitian yang dilakukan Pranandari (2008) yang berjudul "Kecerdasan Adversitas Ditinjau dari Pengatasan Masalah Berbasis Permasalahan dan Emosi pada Orang Tua Tunggal Wanita" menunjukkan adanya perbedaan adversity quotient yang signifikan antara problem focused coping dan emotion focused coping, di mana orang tua tunggal wanita yang menggunakan problem focused coping memiliki adversity quotient yang lebih tinggi dibandingkan dengan orang tua tunggal wanita yang menggunakan emotion focused coping. Menurut Wolfolk (dalam Saidah, 2014) bahwa setiap AQ yang dimiliki oleh seseorang dapat dipengaruhi oleh beberapa faktor, yaitu genetika, bakat, kesehatan, kemampuan, karakteristik kepribadian, pendidikan, dan keyakinan diri atau self efficacy.

Berdasarkan uraian di atas, maka peneliti tertarik untuk melakukan penelitian dengan judul "Perbedaan Adversity Quotient Ditinjau Dari Coping Stress dan Self Efficacy". Penelitian ini bertujuan untuk menguji dan mengetahui perbedaan antara AQ yang ditinjau dari CS dan perbedaan AQ ditinjau dari SE. Pada tahun ajaran 2017/2018 jumlah siswa/i kelas X yang diterima adalah sebanyak 227 orang dan pada tahun ajaran 2018/2019 siswa/i yang diterima adalah sebanyak 246 orang. Dari data ini dapat disimpulkan bahwa adanya peningkatan jumlah siswa/i yang diterima di sekolah ini. Sekolah ini juga telah meraih beberapa prestasi di bidang akademik dan non akademik, tetapi prestasi tersebut lebih banyak diraih pada bidang non akademik. Hasil ujian nasional siswa/i di sekolah ini masih mendapatkan nilai yang dikategorikan cukup. Hal ini juga yang membuat peneliti menargetkan sekolah ini menjadi tempat penelitian.

\section{Metode Penelitian}

Populasi adalah keseluruhan dari satuan objek atau subjek yang mempunyai kualitas dan karakteristik tertentu yang akan dipelajari dan ditarik kesimpulan (Sugiyono, 2018). Populasi dari penelitian ini adalah seluruh siswa/i kelas X di SMA Swasta Medan yaitu sebanyak 246 siswa/i. Dengan menggunakan metode disproportionate stratified random sampling yaitu teknik penarikan sampel yang membagi populasi ke dalam kelompok-kelompok atau berdasarkan strata (Tashakkori \& Teddlie, 2003), maka diperoleh subjek penelitian adalah sebanyak 146 siswa/i kelas X jurusan IPA dan IPS. 
Siswa/i terbagi dari delapan kelas yaitu kelas Ki Hajar Dewantara MIA, J.J.Thomson MIA, Stanford Raffles MIA, James Watt MIA, Alquarrismi MIA, Moh.Hatta IS, Moh.Yamin IS, dan Ki Hajar Dewantara IS. Masing-masing kelas ditarik beberapa siswa/i dengan menggunakan tabel penarikan sampel Isaac dan Michael yang menggunakan pendekatan statistik tingkat kesalahan 5\% (Sarwono, 2006).

Tabel 1. Jumlah Subjek Penelitian dari Setiap Kelas

\begin{tabular}{lc}
\hline \multicolumn{1}{c}{ Kelas } & Jumlah Subjek \\
\hline Ki Hajar Dewantara MIA & 15 \\
\hline J.J.Thomson MIA & 22 \\
\hline Stanford Raffles MIA & 22 \\
\hline James Watt MIA & 20 \\
\hline Alquarrismi MIA & 19 \\
\hline Moh.Hatta IS & 20 \\
\hline Moh.Yamin IS & 22 \\
\hline Ki Hajar Dewantara IS & 6 \\
\hline Total & 146
\end{tabular}

Penelitian ini merupakan penelitian kuantitatif yang bersifat komparatif yaitu penelitian yang menganalisis faktor-faktor penyebab terjadinya suatu fenomena dengan membandingkan dua kelompok atau lebih (Nazir, dalam Hamdi \& Bahruddin, 2014). Metode pengumpulan data menggunakan Skala Likert, yaitu skala AQ, skala CS, dan skala SE. Skala AQ terdiri dari 22 aitem pernyataan, dengan 8 aitem pernyataan favourable dan 14 aitem pernyataan unfavourable. Variabel ini diukur berdasarkan dimensi yang dikemukakan oleh Stoltz (2000), yaitu control (kendali), origin dan ownership (asal usul dan pengakuan), reach (jangkauan), dan endurance (daya tahan). Skala CS terdiri dari 20 aitem pernyataan, dengan 7 aitem pernyataan favourable dan 13 aitem pernyataan unfavourable. Variabel ini diukur berdasarkan dimensi yang dikemukakan oleh Lazarus dan Folkman (dalam Davison, dkk., 2006), yaitu problem focused coping dan emotion focused coping. Skala SE terdiri dari 29 aitem pernyataan, dengan 12 aitem pernyataan favourable dan 17 aitem pernyataan unfavourable. Untuk mengukur variabel ini menggunakan teori yang dikemukakan oleh Albert Bandura (dalam Kurniasari, dkk., 2018), yaitu level (tingkatan), generality (keadaan umum), dan strength (kekuatan).

Pada penelitian ini teknik analisis data yang digunakan adalah teknik analisis varian (anova), yaitu sebuah alat uji statistik yang digunakan untuk menguji hipotesis komparatif sampel bila datanya berada pada skala interval atau rasio (Martono, 2011). Analisis data dalam penelitian ini berisikan hasil uji asumsi yang terdiri dari uji normalitas dan uji homogenitas dan hasil pengujian hipotesis. Uji normalitas dilakukan untuk mengetahui apakah variabel penelitian terdistribusi secara normal atau tidak. Uji normalitas yang dilakukan adalah menggunakan uji Kolmogrov Smirnov Test (K-SZ) di mana data dinyatakan berdistribusi normal jika $p>.05$ (Priyanto, 2011). Uji homogenitas merupakan suatu metode untuk mengetahui apakah varian dari populasi itu sama atau tidak, dengan panduan bahwa nilai signifikansinya harus lebih besar dari .05 sehingga dapat dikatakan varian dari 2 kelompok data atau lebih tersebut adalah sama atau homogen (Priyanto, 2011).

Data yang telah diperoleh dari ketiga variabel dikategorisasikan ke dalam jenjang rendah, sedang, dan tinggi. Pengkategorian ini menggunakan kategorisasi berdasarkan signifikansi perbedaan (Azwar, 2012) yaitu pengkategorisasian yang dilakukan dengan menguji signifikansi perbedaan antara mean skor empirik dengan mean skor teoritik.

Berikut diperoleh rentang nilai kategorisasi dan jumlah sampel setiap kategori adalah sebagai berikut:

Tabel 2. Kategorisasi dan Jumlah Sampel AQ

\begin{tabular}{clcccc}
\multicolumn{5}{c}{ Tabel 2. Kategorisasi dan Jumlah Sampel AQ } \\
\hline Variabel & & Rentang Nilai & Kategori & Jumlah $(\mathrm{n})$ & Persentase \\
\hline \multirow{3}{*}{ AQ } & $\mathrm{x}<64$ & Rendah & 70 & $47.9 \%$ \\
\cline { 2 - 5 } & $64 \leq \mathrm{x} \leq 68$ & Sedang & 24 & $16.5 \%$ \\
\cline { 2 - 5 } & $\mathrm{x}>68$ & Tinggi & 52 & $35.6 \%$ \\
\hline & & & 146 & $100 \%$
\end{tabular}

Tabel 3. Kategorisasi dan Jumlah Sampel CS

\begin{tabular}{|c|c|c|c|c|}
\hline Variabel & Rentang Nilai & Kategori & Jumlah (n) & Persentase \\
\hline \multirow{3}{*}{ CS } & $x<58$ & Rendah & 37 & $25.3 \%$ \\
\hline & $58 \leq x \leq 61$ & Sedang & 31 & $21.2 \%$ \\
\hline & $x>61$ & Tinggi & 78 & $53.5 \%$ \\
\hline & Total & & 146 & $100 \%$ \\
\hline
\end{tabular}


Tabel 4. Kategorisasi dan Jumlah Sampel SE

\begin{tabular}{clcccc}
\hline Variabel & & Rentang Nilai & Kategori & Jumlah (n) & Persentase \\
\hline \multirow{3}{*}{ SE } & $\mathrm{x}<85$ & Rendah & 59 & $40.4 \%$ \\
\cline { 2 - 5 } & $85 \leq \mathrm{x} \leq 89$ & Sedang & 26 & $17.8 \%$ \\
\cline { 2 - 5 } & $\mathrm{x}>89$ & Tinggi & 61 & $41.8 \%$ \\
\hline \multirow{2}{*}{ Total } & & 146 & $100 \%$
\end{tabular}

\section{Hasil dan Pembahasan}

Hasil dari uji normalitas untuk variabel AQ menunjukkan nilai K-SZ sebesar .713 dengan nilai Sig. sebesar .689, untuk variabel CS menunjukkan nilai K-SZ sebesar 1.072 dengan nilai Sig. sebesar .201, dan untuk variabel SE menunjukkan nilai K-SZ sebesar .609 dengan nilai Sig. sebesar .852. Dapat dilihat bahwa nilai Sig. lebih besar dari .05 maka dari data yang diperoleh dinyatakan berdistribusi normal antara AQ, CS dan SE. Hasil uji homogenitas menunjukkan bahwa AQ ditinjau dari CS memiliki Sig. sebesar .300 dan AQ ditinjau dari SE memiliki Sig. sebesar .306, di mana Sig, tersebut lebih besar dari .05 $(p>.05)$ maka dapat dikatakan bahwa kelompok yang diuji bersifat homogen. Hasil uji hipotesa anova menunjukkan bahwa AQ ditinjau dari CS memiliki nilai F hitung sebesar 14.876 dengan nilai Sig. sebesar $.000<\mathrm{p}=.05$ dan hasil uji hipotesa anova menunjukkan AQ ditinjau dari SE memiliki nilai F hitung sebesar 11.664 dengan nilai Sig. sebesar $.000<p=.05$. Maka dapat disimpulkan $\mathrm{F}$ hitung $>\mathrm{F}$ tabel, yang berarti hipotesa penelitian terbukti yaitu adanya perbedaan AQ ditinjau dari CS dan SE.

AQ menurut Stoltz (2000) dibagi menjadi tiga tipe individu yang diibaratkan sedang dalam perjalanan mendaki gunung, yaitu yang pertama adalah tipe quitters, pendaki dengan tipe ini cenderung memilih untuk berhenti mendaki, dalam kehidupan sehari-hari tipe quitters lebih memilih untuk menghindar dari kewajiban, memilih untuk mundur dari kesulitannya, memilih untuk keluar dari kesulitan tanpa menyelesaikannya dan bahkan berhenti sebelum masalah tersebut terselesaikan. Individu dengan tipe quitters ini memiliki AQ yang dikategorikan pada tingkatan yang rendah (low-AQ). Tipe kedua yaitu campers, pendaki dengan tipe ini adalah mereka yang cepat merasa bosan selama pendakian, memilih untuk berhenti di tengah-tengah pendakian dan mencari tempat yang datar dan nyaman untuk berkemah, jika dikaitkan dengan kehidupan sehari-hari, individu dengan tipe campers lebih baik daripada individu dengan tipe quitters, karena individu dengan tipe campers ini mau memulai dan mencoba untuk menyelesaikan kesulitannya walaupun tidak secara maksimal, mereka berhenti di tengah-tengah jalan karena merasa bosan terhadap permasalahannya, alhasil permasalahan yang dihadapi individu tidak terselesaikan dengan baik. Hal ini menunjukkan bahwa individu dengan tipe campers memiliki AQ pada tingkatan sedang (moderat-AQ). Tipe yang ketiga yaitu tipe climbers, pendaki yang mencapai garis final, mereka yang seumur hidup membaktikan diri pada pendakian, mereka yang pantang menyerah dan terus berjuang tanpa memperhatikan keuntungan dan kerugian, baik itu nasib buruk atau baik mereka tetap mendaki. Jika dikaitkan dengan kehidupan sehari-hari, tipe climbers ini merupakan individu yang terus berjuang untuk menyelesaikan kesulitan yang dihadapi dan tipe inilah yang paling baik dari tipe-tipe lainnya, karena tipe climbers tidak menyerah kepada situasi dan terus-menerus mencari cara untuk menyelesaikan kesulitan yang dihadapi. Hal ini menunjukkan bahwa individu dengan tipe climbers memiliki tingkatan AQ yang tinggi (high-AQ).

Dari data Tabel 2 dapat diketahui bahwa terdapat 52 siswa/i yang memiliki AQ yang tinggi (climbers), 24 siswa/i memiliki AQ sedang (campers), dan 70 siswa/i memiliki AQ rendah (quitters). Siswa/i yang memiliki AQ yang tinggi berarti memiliki ketahanan dan kemampuan yang lebih baik dalm mengatasi kesulitan. Hal ini sejalan dengan penjelasan Stoltz (dalam Wibowo, 2015), bahwa individu yang memiliki AQ tinggi diharapkan mampu mengambil keputusan yang sesuai untuk bertindak sehingga mampu mengatasi kesulitan dan menjadikan hal tersebut sebagai motivator dalam mencapai tujuannya di masa yang akan datang. Selain itu, hasil penelitian (Tabel 3) juga menunjukkan sebanyak 78 siswa/i memiliki CS yang tinggi, 31 siswa/i yang memiliki CS yang sedang, dan 37 siswa/i memiliki CS yang rendah. Dalam penelitian ini subjek lebih menggunakan emotion focused coping, yang terlihat dari siswa/i dalam mengatasi stres untuk menghadapi ujian, mereka menunjukkan penyangkalan, di mana mereka menyalahkan situasi dan kondisi di luar diri mereka seperti ujian yang dilaksanakan pada bulan puasa, penjelasan guru yang kurang baik, dan sarana serta prasarana yang tidak mendukung proses pembelajaran. Siswa/i dengan CS tinggi diharapakan mampu menemukan solusi untuk menyelesaikan kesulitan yang dihadapi dengan 
menggunakan strategi coping yang baik. Hasil penelitian ini juga memaparkan data terkait SE (Tabel 4), terdapat 61 siswa/i yang memiliki SE tinggi, 26 siswa/i yang memiliki SE sedang, dan 59 siswa/i yang memiliki SE rendah. Siswa/i yang memiliki SE tinggi berarti siswa/i tersebut memiliki keyakinan terhadap kemampuan yang dimilikinya. Senada dengan hasil penelitian sebelumnya oleh Luszczynska, dkk., (2005) menyatakan bahwa individu dengan SE yang tinggi akan merasa lebih tertantang terhadap tugas-tugas yang memiliki tekanan daripada individu yang memiliki SE rendah. Bandura (dalam Wibowo, 2015) juga menyatakan bahwa individu dengan SE yang tinggi akan bersikap lebih prososial, lebih popular di kalangan teman-temannya, dan sangat jarang menerima penolakan dari teman sebayanya dibandingkan dengan individu yang memiliki SE yang rendah, dan juga individu dengan SE yang rendah cenderung memiliki emosi yang kurang stabil, sering menunjukkan perilaku agresi baik secara fisik maupun verbal serta adanya kemungkinan individu untuk melanggar aturanaturan yang ada.

Penelitian ini membuktikan bahwa hipotesis diterima dan menghasilkan uji $\mathrm{F}$ dengan $\mathrm{p}=.000$, yaitu $\mathrm{F}$ hitung $=14.876>\mathrm{F}$ tabel $=3.06$, artinya ada perbedaan $\mathrm{AQ}$ ditinjau dari $\mathrm{CS} ; \mathrm{F}$ hitung $=11.664>\mathrm{F}$ tabel $=3.06$, artinya terdapat perbedaan AQ ditinjau dari SE yang dimiliki oleh siswa/i. Hasil analisis regresi dapat dilihat dari nilai $R$ Square menunjukkan bahwa CS mempengaruhi AQ sebesar $16.6 \%(\beta$ $=.408 ; p=.00 ; p<.05)$ dan SE mempengaruhi AQ sebesar 19.5\% $(\beta=.442 ; p=.00 ; p<.05)$, dan selebihnya dipengaruhi oleh faktor-faktor lain yang tidak diteliti dalam penelitian ini.

\section{Kesimpulan}

Berdasarkan uraian di atas dapat disimpulkan bahwa terdapat perbedaan adversity quotient (AQ) ditinjau dari coping stress (CS), dan self efficacy (SE). Saran yang dapat diberikan peneliti kepada siswa/i dalam meningkatkan AQ, CS, dan SE adalah dengan cara membentuk suatu pola pikir bahwa belajar itu merupakan hal yang menyenangkan sehingga diharapkan dapat menimbulkan minat belajar para siswa/i dan tidak ragu bertanya kepada guru jika ada mata pelajaran yang kurang dimengerti. Saran kepada pihak sekolah dalam membantu siswa/i untuk meningkatkan AQ, CS, dan SE adalah dengan menerapkan metode pembelajaran yang lebih menarik seperti membentuk kelompok belajar dan menerapkan proses pembelajaran di luar kelas. Bagi peneliti selanjutnya diharapkan untuk dapat meneliti faktor-faktor lain yang mempengaruhi AQ seperti bakat, kemampuan, kepribadian, genetika, dan pendidikan.

Implikasi dari penelitian ini yaitu dapat memberikan sumbangsi kepada ilmu psikologi khususnya psikologi kepribadian, psikologi pendidikan, dan psikologi perkembangan, bagi siswa/i dapat memberikan CS dalam mengatasi stres yang mereka hadapi dan juga bagi sekolah dapat dijadikan sebagai bahan pertimbangan dalam menyusun pembelajaran dengan metode dan media pembelajaran yang dapat mengembangkan kemampuan siswa/i.

\section{Daftar Rujukan}

Kamus Besar Bahasa Indonesia. Diakses pada November 8, 2018. Tersedia di: https://kbbi.web.id/.

Widarnandana, I. G. D., \& Simarmata, N. (2015). Pengaruh outbond terhadap efikasi diri pada mahasiswa. Jurnal Psikologi Udayana, 2 (2), pp.151-162.

Yusuf, S. (2001). Psikologi Perkembangan Anak \& Remaja. Bandung: Remaja Rosdakarya.

P, A. T. D., \& Desiningrum, D. R. (2018). Hubungan secure attachment dengan ibu dan kecenderungan berperilaku agresi pada siswa SMA N 2 Ungaran. Jurnal Empati, 7 (3), pp.80-89.

Cisilia Agustina S, 2016. Duh, Siswa Ketahuan Bawa HP Saat UN Di Taruh Di Paha [Online] (Update 05 April 2016) Tersedia di : https//bali.tribunnews.com/2016/04/05/duh-siswa-ketahuan-bawa-hp-saat-ditaruhdi-antara-paha. [Acessed 08 November 2018].

Stoltz, P. (2000). Adversity Quotient: Mengubah Hambatan Menjadi Peluang. Jakarta: PT.Grasindo.

Maryam, S. (2017). Strategi coping: Teori dan sumberdaya. Jurnal Konseling. Andi Mattapa, 1 (2), pp.101-107. doi = http://dx.doi.org/10.31100/jurkam.v1i2.12.

Davison, G. C., Neale, J. M., \& Kring, A. M. (2006). Psikologi Abnormal. Jakarta: PT. Rajagrafindo Persada Rahmi, S., Nadia, R., Hasibah, B., \& Hidayat, W. (2017). The relation between self efficacy toward math with the math communication competence. Journal of Mathematics Education, 6 (2), pp.177-182. doi = https://doi.org/10.22460/infinity.v6i2.p177-182.

Ghufron, M. N., \& Risnawita, R. (2018). Teori-teori Psikologi. Jogjakarta: Ar-Ruzz Media. 
Diny Atrizka, Kevin Sanjaya, Dea Vanthera, Wulandari, Khrisna Sanubari Limbong, Rizky Yusfasari

Psyche 165 Journal Vol 13 No 02 (2020) 263 - 268

Kurniasari, R., Dariyo, A., \& Idulfilastri, R. M. (2018). Hubungan antara self efficacy dengan pengambilan keputusan karier pada mahasiswa tingkat akhir fakultas Psikologi (Studi kasus pada Universitas di Jakarta Barat). Journal An-nafs, 3 (1), pp.1-19. doi = https://doi.org/10.33367/psi.v3i1.497.

Pranandari, K. (2008). Kecerdasan adversitas ditinjau dari pengatasan masalah berbasis permasalahan dan emosi pada orang tua tunggal wanita. Jurnal Psikologi, 1 (2), pp.121-128.

Saidah, S., \& Aulia, A. A. (2014). Hubungan self efficacy dengan adversity quotient (AQ). Jurnal Psikologi, 2 (2), pp.54-61.

Sugiyono. (2018). Metodologi Penelitian Kuantitatif, Kualitatif, Dan R\&D. Bandung: Alfabeta.

Tashakkori, A., \& Teddlie, C. (2003). Hanbook of Mixed Methods in Social \& Behavioral Research. California: Sage Publication, Inc.

Sarwono, J. (2006). Metode Penelitian Kuantitatif \& Kualitatif. Yogyakarta: Graha Ilmu.

Hamdi, A. S., \& Bahruddin, E. (2014). Metode Penelitian Kuantitatif Aplikasi Dalam Pendidikan. Yogyakarta: CV. Budi Utama.

Martono, N. (2011). Metode Penelitian Kuantitatif: Analisis Isi dan Analisis Data Sekunder. Jakarta: PT.Rajagrafindo Persada.

Priyanto, D. (2011). Buku Saku SPSS Analisis Statistic Data Lebih Cepat, Efisien, dan Akurat. Yogyakarta: Media Kom.

Azwar, S. (2012). Penyusunan Skala Psikologi Edisi 2. Yogyakarta: Pustaka Pelajar.

Wibowo, M. W. (2015). Hubungan antara kecerdasan emosi, adversity quotient, dan efikasi diri pada siswa kelas XII Madrasah Aliyah Negeri 1 Magelang. Jurnal Psikologi Tabularasa, 10 (2), pp.186-200.

Luszczynska, A., Guitierrez-Dona, B., Schwarzer, R. (2005). General self efficacy in various domains of human functioning: Evidence from five countries. International Journal of Psychology, 40 (2), pp.80-89. doi = https://doi.org/10.1080/00207590444000041. 